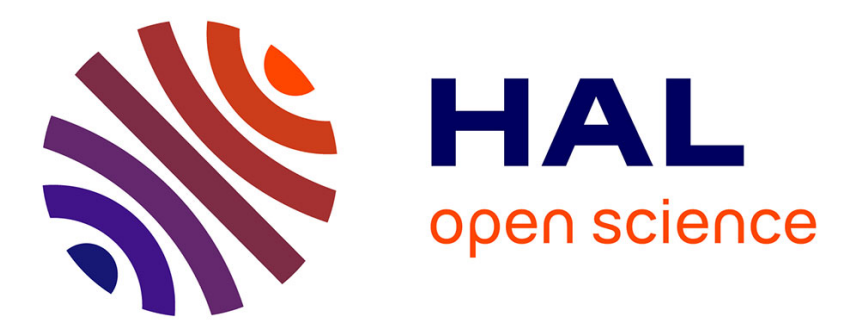

\title{
Information chain modeling from product to stakeholder in the use phase - Application to diagnoses in railway transportation
}

Vivien Basselot, Thierry Berger, Yves Sallez

\section{- To cite this version:}

Vivien Basselot, Thierry Berger, Yves Sallez. Information chain modeling from product to stakeholder in the use phase - Application to diagnoses in railway transportation. Manufacturing Letters, 2019, 20, pp.22-26. 10.1016/j.mfglet.2019.03.001 . hal-03426755

\section{HAL Id: hal-03426755 \\ https://uphf.hal.science/hal-03426755}

Submitted on 20 Dec 2021

HAL is a multi-disciplinary open access archive for the deposit and dissemination of scientific research documents, whether they are published or not. The documents may come from teaching and research institutions in France or abroad, or from public or private research centers.
L'archive ouverte pluridisciplinaire HAL, est destinée au dépôt et à la diffusion de documents scientifiques de niveau recherche, publiés ou non, émanant des établissements d'enseignement et de recherche français ou étrangers, des laboratoires publics ou privés.

\section{(ㄷ)(1) $\$$}

Distributed under a Creative Commons Attribution - NonCommercial| 4.0 International 


\title{
Information chain modeling from product to stakeholder in the use phase - Application to diagnoses in railway transportation
}

\author{
Authors: \\ Vivien Basselot, Thierry Berger, Yves Sallez \\ Affiliation address: \\ Univ. Polytechnique Hauts-de-France, UMR 8201 - LAMIH - \\ Laboratory of Industrial and Human Automation control Mechanical \\ engineering and Computer science, F-59313 Valenciennes, France \\ CNRS, UMR 8201, F-59313 Valenciennes, France \\ e-mail addresses: \\ \{vivien.basselot,thierry.berger,yves.sallez\}@uphf.fr
}

Corresponding author: Vivien Basselot

\begin{abstract}
In the field of Product Lifecycle Management, the gaps in terms of Product Usage Data collection and exploitation must be addressed. The proposal addresses the modeling of the information chain from the product to the stakeholder. This model considers the product and its context composed of the user, task, and environment. It exploits a holonic view of the product and a dynamic informational structure to store the data, information, and knowledge collected on the product and its context during various instances of usage. The proposed model is applied to the diagnosis of equipment in the field of railway transportation.
\end{abstract}

Keywords: product usage data, active product, closed-loop PLM, railway transportation 


\section{Introduction and motivations}

A product lifecycle is generally divided into three phases: Beginning-of-Life (BOL), Middle-of-Life (MOL) and End-of-Life (EOL). Even if Product Lifecycle Management (PLM) is considered to cover all the phases of the product lifecycle [2], it often focuses on the BOL and so data in other phases are not sufficiently considered $[1,3]$ resulting in losses in the value chain [4]. Bridging the need for data from the phases after the BOL becomes very critical for the product provider (and stakeholders in general) to improve the product, optimize costs, and be competitive. MOL product usage data (PUD) can be made available to all stakeholders concerned through an information chain and exploited to improve product use performance and product management, for example. PUD can be used [5] for marketing, reliability, servicing, preventive maintenance, warranty returns or repair, for example. PUD are dynamic and can include component running times or environmental conditions that may affect the durability of parts [6]. In this context, the closed-loop PLM approach [1] exploits PUD and generates feedback to the EOL to improve recycling/recovery decisions [7] or to the BOL to improve the next generation of products [8].

Generally, studies are based on three key elements [3]: an augmentation module that increases the product informational capabilities and helps gather the PUD required to manage the product throughout its lifecycle; an infrastructure for storing and enriching data; data promotion by stakeholders.

Several research projects exploiting PUD can be cited and are summarized in Table 1 according to the aforementioned key elements.

\begin{tabular}{|c|c|c|c|c|c|}
\hline $\begin{array}{c}\text { Project } \\
\text { - Year of } \\
\text { publication - } \\
\end{array}$ & Objective & $\begin{array}{l}\text { Product/field } \\
\text { concerned }\end{array}$ & $\begin{array}{l}\text { Augmentation } \\
\text { module }\end{array}$ & PUD collection & $\begin{array}{c}\text { Product Usage } \\
\text { Data }\end{array}$ \\
\hline $\begin{array}{c}\text { CARE [9] } \\
-1994-\end{array}$ & Recycling, reusing & Electronic modules & $\begin{array}{c}\text { ID (identification) } \\
\text { unit }\end{array}$ & $\begin{array}{l}\text { Read out later by } \\
\text { wired interface }\end{array}$ & $\begin{array}{l}\text { Recycling and reuse } \\
\text { data }\end{array}$ \\
\hline $\begin{array}{l}\text { WHITEBOX } \\
-2000-\end{array}$ & $\begin{array}{l}\text { Design, marketing and } \\
\text { servicing, end-of-life }\end{array}$ & Domestic appliances & $\begin{array}{c}\text { LCDA (life cycle } \\
\text { data acquisition) } \\
\text { device }\end{array}$ & $\begin{array}{l}\text { Read out later by } \\
\text { wired interface }\end{array}$ & $\begin{array}{c}\text { Pattern of use and } \\
\text { individual appliance } \\
\text { program cycles }\end{array}$ \\
\hline $\begin{array}{l}\text { ELIMA }[3] \\
-2007-\end{array}$ & $\begin{array}{l}\text { Lifecycle information } \\
\text { and knowledge }\end{array}$ & Consumer goods & $\begin{array}{l}\text { IDU (intelligent } \\
\text { data unit) }\end{array}$ & $\begin{array}{c}\text { Communication } \\
\text { Support Infrastructure }\end{array}$ & $\begin{array}{c}\text { Distribution, usage, } \\
\text { maintenance and end- } \\
\text { of-life data }\end{array}$ \\
\hline $\begin{array}{l}\text { PROMISE [10] } \\
\text { - } 2011 \text { - }\end{array}$ & $\begin{array}{l}\text { Transfer of critical } \\
\text { information about a } \\
\text { product back to the } \\
\text { earlier design and } \\
\text { forward to appropriate } \\
\text { intervention area }\end{array}$ & $\begin{array}{l}\text { Mainly any type of high } \\
\text { value-added product }\end{array}$ & $\begin{array}{c}\text { PEID } \\
\text { (product embedded } \\
\text { information device) }\end{array}$ & $\begin{array}{l}\text { Information and } \\
\text { related emerging } \\
\text { technologies }\end{array}$ & $\begin{array}{l}\text { Lifecycle monitoring } \\
\text { data }\end{array}$ \\
\hline $\begin{array}{c}\text { FALCON } \\
\text { - } 2011 \text { - }\end{array}$ & $\begin{array}{l}\text { Creation of new } \\
\text { products and value- } \\
\text { adding services }\end{array}$ & $\begin{array}{l}\text { High-Tech healthcare } \\
\text { products, Clothing- } \\
\text { textiles, White and } \\
\text { brown Goods }\end{array}$ & $\begin{array}{l}\text { PEID-IoT (Internet } \\
\text { of things) device }\end{array}$ & $\begin{array}{c}\text { Information and IoT } \\
\text { communication } \\
\text { technologies }\end{array}$ & $\begin{array}{l}\text { Customer feedback } \\
\text { and usage } \\
\text { information data }\end{array}$ \\
\hline $\begin{array}{l}\text { ICP4LIFE [12] } \\
\quad-2018-\end{array}$ & $\begin{array}{l}\text { Design, development } \\
\text { and support of product- } \\
\text { service systems }\end{array}$ & $\begin{array}{c}\text { Equipment } \\
\text { manufacturers and } \\
\text { energy suppliers }\end{array}$ & $\begin{array}{c}\text { IIoT (Industrial } \\
\text { Internet of Things) } \\
\text { device }\end{array}$ & $\begin{array}{c}\text { Information and IIoT } \\
\text { communication } \\
\text { technologies }\end{array}$ & $\begin{array}{l}\text { Equipment and } \\
\text { process data }\end{array}$ \\
\hline
\end{tabular}

Table 1. Survey of research

From the first to the last, the projects are based increasingly on internet technologies. Although these studies are valuable contributions, they do not provide a generic model to help with decision-making or the capture, collection, storage, processing, and promotion of product usage data (PUD). With this modeling, the main issues concern:

- the complexity of a product composed of several sub-systems,

- $\quad$ the product ecosystem (users, context...),

- the diversity of the stakeholders and operating needs of the PUD,

- the multiple use of PUD with varying semantics. 


\section{Proposition}

\subsection{The product and its ecosystem}

From a functional point of view, the product, denoted $\boldsymbol{P}_{\boldsymbol{i}}$, is assumed to provide services associated with a set of primary functions to a user or users (for example, the primary function of a railway vehicle door is to allow passengers access). As illustrated by the example in Fig. 1, the product (1) is immersed in a context composed of the following:

- $\quad$ The user (2) defined as someone who interacts directly with the product in accordance with the primary function considered (e.g., operator, installation driver, passengers).

- The task (3), which defines how the product is used for a given primary function (e.g., opening doors), is characterized by a prescribed use procedure and performance criteria (e.g., quality of the result, processing time).

- The environment (4) depicts the environmental situation (e.g., physical, energetic, regulatory) in which the task occurs.

During the use phase, the operational product executes all or part of its primary functions but also requires secondary functions. The latter are used to improve performance criteria (e.g., availability via predictive maintenance functionalities) and to generate information flows to the BOL and EOL phases.

The support systems (5) support these secondary functions. An augmentation module supports a set of secondary functions and an external support system supports the remaining secondary functions. For example, for condition-based maintenance, an augmentation module (e.g., vibration monitoring system) physically linked to a product can send diagnostic data via an informational link to an external support system (e.g., remote maintenance center).

The stakeholders (6) are defined as any entity (human or artificial) in need of information/knowledge to make decisions to improve the value chain associated with the product (e.g., product provider).

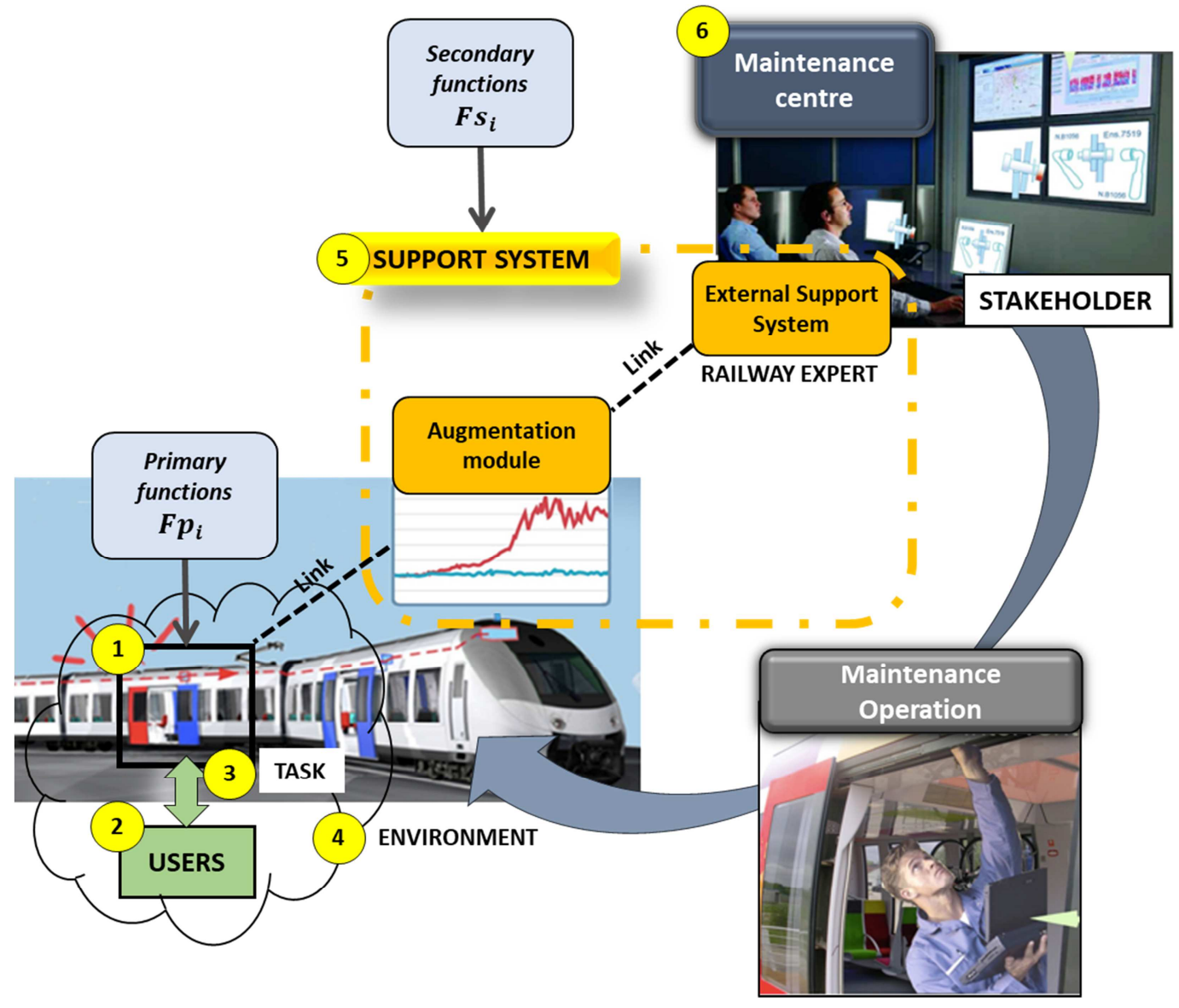

Fig. 1. Illustration of the primary and secondary functions 


\subsection{Modeling of the secondary functions}

Holonic architecture: As illustrated in Fig. 3, a holonic architecture was retained to deal with the decomposition of a product into several sub-systems that may themselves be decomposed into sub-systems [13]. A triplet $\left(\boldsymbol{F} \boldsymbol{s}_{\boldsymbol{i}}, \boldsymbol{P}_{\boldsymbol{i}}, \boldsymbol{C}_{\boldsymbol{i}}\right)$ is associated with each holon $\boldsymbol{H}_{i}$. The set $\mathbf{F s}_{\mathbf{i}}$ of secondary functions, and the product $\boldsymbol{P}_{\boldsymbol{i}}$ and its context $\boldsymbol{C}_{\boldsymbol{i}}$ constitute the head and the body of the holon, respectively. Collaborative relationships exist equally among holons located at levels $1-1,1$ and $1+1$.

Decisional process and informational structures: As illustrated in Fig. 2, a decisional process is associated with each secondary function and exploits the following:

- Information flows arising from collaboration between holons in the hierarchical structure.

- Subsets of the static informational structure SIS $_{i}$. This structure contains static data, information, and knowledge relating to the product (e.g., technical description, model behavior, and prescribed task). Product data knowledge management systems can support this structure in a closed-loop PLM context.

- Subsets of the dynamic informational structure DIS $_{i}$ containing the PUD, collected during the different use instances. The dynamic informational structure (DIS) constitutes the informational backbone used by the different operations associated with the secondary functions.

The previous informational structures are built according to a DIK model:

- D (for Data) are raw facts without meaning resulting from measurements (e.g., weight, temperature, current) obtained using sensors (embedded in the product or located in its context).

- I (for Information) is obtained by adding tags to data giving informative details such as "when", "where", "who", "how", "what" (e.g., door (what) current in a vehicle (where) at specific date and time (when)).

- K (for Knowledge) represents expertise and can be seen as groups of information that are linked by semantic relations (e.g., door $\mathrm{P}_{132}$ used in vehicle $\mathrm{P}_{13}$ in an operational context where the weight of the passengers near the door is $520 \mathrm{~kg}$ ). Knowledge is described using ontologies [14].

The "usage" ontology has to be considered as an upper ontology [15] because details depend specifically on the product, user, task, and environment considered. This upper ontology is used as a generic model, built as simply as possible, and represents the semantic relations between different types of information.

The decisional process is organized according to three levels inspired from the modeling introduced by Rasmussen [16]:

- At lower level, reactive behavior (or skill-based behavior) exploiting basic data is able to generate alarms. For example, during an instance of product use, an embedded system equipped with sensors detects a misuse (e.g., the current measured for the door is too high) and generates an alarm.

- At mid-level, rule-based behavior can exploit the different sources of information to generate refined information. For example, in a maintenance context, a diagnostic procedure can generate a list of components that may be implicated and send it to a remote maintenance center.

- At higher level, the processing operations exploit knowledge stored in the DIS structure to improve understanding of the use situations. For example, a detailed analysis of the context for several instances of usage can lead to a more precise diagnosis of a product failure.

The output elaborated, out $\boldsymbol{i}_{i}$, is transmitted to the stakeholder who can decide whether to intervene on the product or not. 


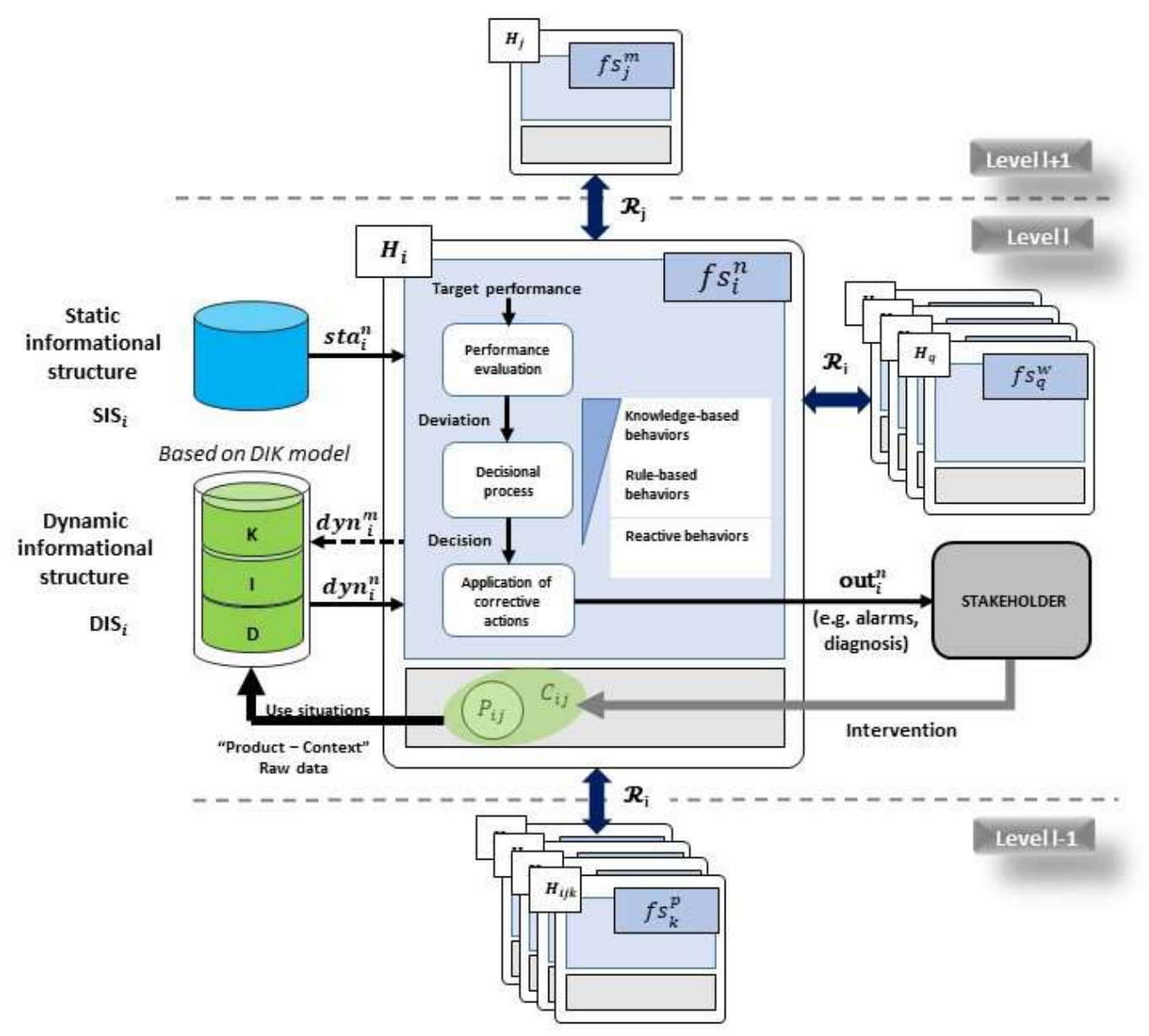

Fig. 2. Description of the decisional process

\section{Use Case}

This use case concerns the diagnosis of railway equipment and was inspired from previous studies [17]. It focuses on the secondary function "door diagnosis", which consists in exploring the context to find clues that explain the variables qualifying the product and its "health". A human expert working in a maintenance center supports this diagnostic activity. This expert liaises with the stakeholder concerned (who decides to launch maintenance work if necessary).

The lower part of Fig. 3 illustrates the different measurements collected and stored in the DIS structure. Some technical data are collected directly from the door and other data, relative to the context, are collected from the three levels of the train architecture. The decisional process relative to the diagnosis is "knowledge-based" and requires cognitive activity from the railway expert.

As illustrated in Fig. 3, the maximum current for door $\mathrm{P}_{132}$ was monitored and an alarm was triggered. A contextual analysis highlighted that the weight of the passengers near the door was considerable (i.e. weight $=$ $520 \mathrm{~kg}$ ) and could explain why the current measured was higher than the six-amp threshold. So, the problem detected was diagnosed as a contextual problem and not the deterioration of the door. This is a concrete example of the exploitation of the "usage" ontology and the link with the time-series information related to the door. 


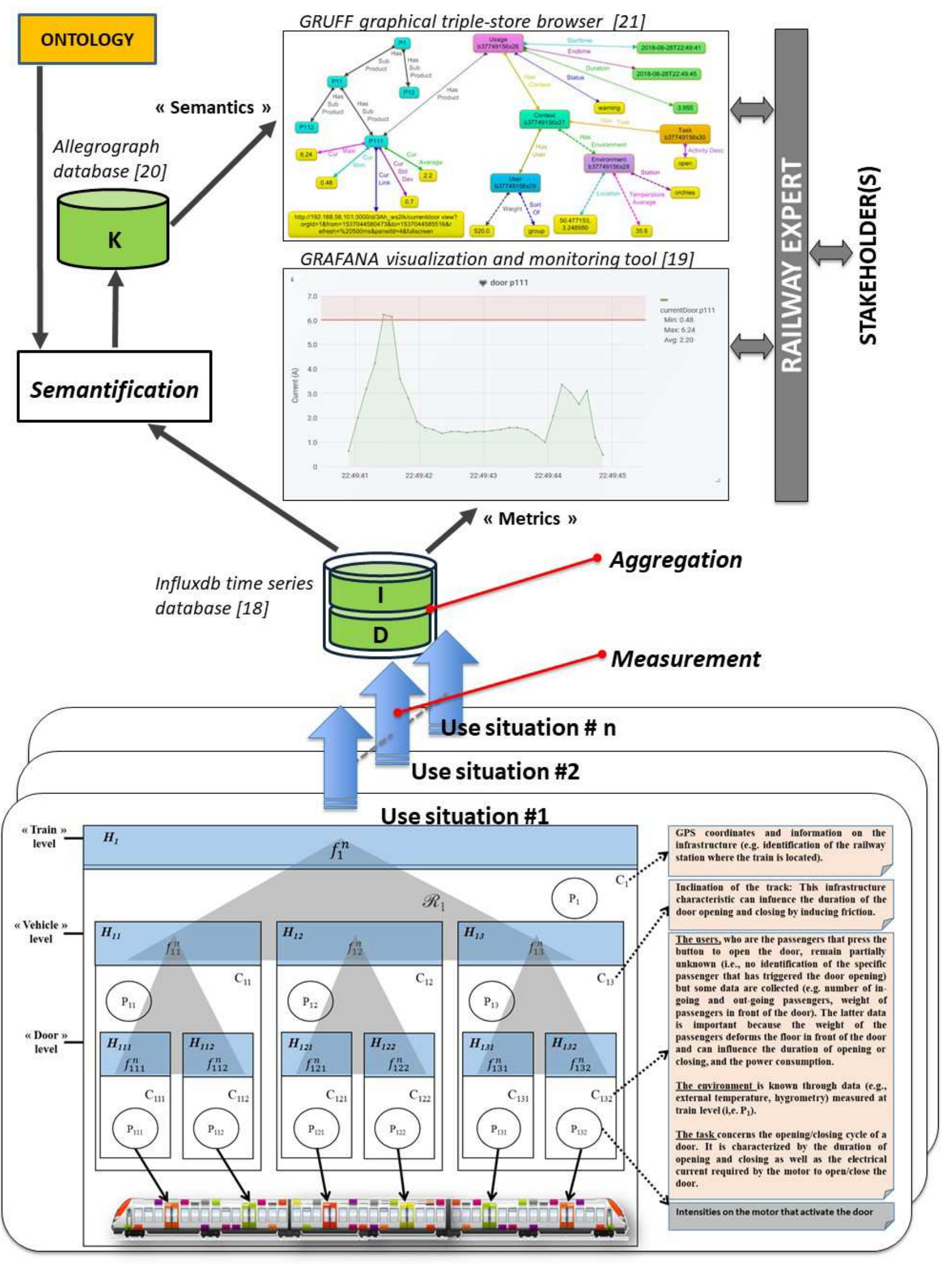

Fig. 3. Holonic architecture and tools used by the expert 


\section{Conclusion}

This paper, in the field of closed-loop PLM, proposes a model of the informational chain from the product use situation to the stakeholders. This model considers the product and its context composed of the user, task, and environment. Associated with the secondary function, the DIS, which exhibits data, information, and knowledge, has to be considered as the backbone feeding the different processes organized in three levels of cognitive complexity.

The next step will be to complete our proposition with detailed guidelines on how to exploit and use the proposed model in a generic case taking all kind of products into consideration and to help select the implementation architecture.

\section{References}

[1] Jun HB, Kiritsis D, Xirouchakis P. Research issues on closed-loop PLM. Comput Ind 2007;58:855-68. doi:10.1016/j.compind.2007.04.001.

[2] Taisch M, Cammarino BP, Cassina J. Life cycle data management: first step towards a new product lifecycle management standard. Int J Comput Integr Manuf 2011;24:1117-35.

[3] Yang X, Moore PR, Wong C-B, Pu J-S, Kwong Chong S. Product lifecycle information acquisition and management for consumer products. Ind Manag Data Syst 2007;107:936-53.

[4] van der Vegte WF. Taking Advantage of Data Generated by Products: Trends, Opportunities and Challenges. ASME 2016 Int. Des. Eng. Tech. Conf. Comput. Inf. Eng. Conf., 2016, p. V01BT02A025-V01BT02A025.

[5] Simon M, Bee G, Moore P, Pu J-S, Xie C. Modelling of the life cycle of products with data acquisition features. Comput Ind 2001;45:111-22.

[6] Simon M, Bee G, Moore P, Pu J-S, Xie C. Life cycle data acquisition unit-design, implementation, economics and environmental benefits. Electron. Environ. 2000. ISEE 2000. Proc. 2000 IEEE Int. Symp., 2000, p. 284-9.

[7] Cao H, Folan P, Lu Z, Mascolo J, Francone N, Browne J. Design of an end-of-life decision support system using product embedded information device technology. Technol. Manag. Conf. (ICE), 2006 IEEE Int., 2006, p. 1-8.

[8] Igba J, Alemzadeh K, Gibbons PM, Henningsen K. A framework for optimising product performance through feedback and reuse of in-service experience. Robot Comput Integr Manuf 2015;36:2-12.

[9] Scheidt L, Zong S. An approach to achieve reusability of electronic modules. Electron. Environ. 1994. ISEE 1994., Proceedings., 1994 IEEE Int. Symp., 1994, p. 331-6.

[10] Kiritsis D. Closed-loop PLM for intelligent products in the era of the Internet of things. Comput Des 2011;43:479-501.

[11] FALCON H2020 n.d. http://www.falcon-h2020.eu/ (accessed February 27, 2019).

[12] Project - ICP4LIFE n.d. http://www.icp4life.eu/project/ (accessed February 27, 2019).

[13] Koestler A. The ghost in the machine 1967.

[14] Noy NF, McGuinness DL, others. Ontology development 101: A guide to creating your first ontology 2001.

[15] Mascardi V, Cordì V, Rosso P. A Comparison of Upper Ontologies. Woa, vol. 2007, 2007, p. 55-64.

[16] Rasmussen J. Skills, rules, and knowledge; signals, signs, and symbols, and other distinctions in human performance models. IEEE Trans Syst Man Cybern 1983:257-66.

[17] Le Mortellec A, Clarhaut J, Sallez Y, Berger T, Trentesaux D. Embedded holonic fault diagnosis of complex transportation systems. Eng Appl Artif Intell 2013;26:227-40.

[18] InfluxData (InfluxDB) n.d. https://www.influxdata.com/ (accessed February 27, 2019).

[19] Grafana - analytics and monitoring n.d. https://grafana.com/ (accessed February 27, 2019).

[20] AllegroGraph n.d. https://allegrograph.com/ (accessed February 27, 2019).

[21] Gruff | AllegroGraph n.d. https://allegrograph.com/products/gruff/ (accessed February 27, 2019). 